\title{
A Psychological Counseling Study on Fear of Failure and Academic Procrastination with a Spiritually Oriented Cognitive Behavioral Group
}

\author{
Serra Dinç ${ }^{1 \oplus}$ \\ University of Health Sciences
}

\author{
Halil Ekssii ${ }^{2} \odot$ \\ Marmara University
}

\begin{abstract}
This study aims to investigate the effectiveness of psychological counseling with an eight-session group study based on the spiritually oriented cognitive behavioral approach, which was developed to reduce high school students' fear of failure and academic procrastination levels. The study uses an experimental design with a pretest-posttest control group. The sample group of the study consists of 20 female students (10 experimental and 10 controls) attending 11th grade at an Imam Hatip High School in the Üsküdar District of Istanbul during the 2018-2019 academic year. The experimental and control groups were applied the Error Making Anxiety Subscale of the Frost Multidimensional Perfectionism Scale and the Academic Procrastination Scale as the pre-tests and post-tests. Spiritually oriented cognitive behavioral psychological counseling was conducted in 90-minute sessions for eight weeks. The nonparametric Mann-Whitney U test has been used to determine whether a difference exists between the pre-test and post-test scores of the experimental and control groups. The non-parametric Wilcoxon signed-rank test has been used to test whether significant differences exist between the fear of failure and academic procrastination pre-test and post-test scores for both the control and experimental groups. As a result of the study, the psychological counseling with spiritually oriented cognitive behavioral group study was found to have an effect on fear of failure and academic procrastination. The results have been discussed last.
\end{abstract}

\section{Keywords}

Fear of failure $\bullet$ Academic procrastination $\bullet$ Spirituality $\bullet$ Cognitive behavioral approach

\section{Başarısızlık Korkusu ve Akademik Erteleme Üzerine Manevi Yönelimli Bilişsel Davranışçı Grupla Psikolojik Danışma Çalışması}

Öz

$\mathrm{Bu}$ araştırmada lise öğrencilerinin başarısızlık korkularını ve akademik erteleme düzeylerini azaltmak için geliştirilen manevi yönelimli bilişsel davranış̧̧ı yaklaşımı temel alan 8 oturumluk grupla psikolojik danışmanlık çalışmasının etkinliğini incelemek amaçlanmıştır. Çalışmada ön-test son-test kontrol gruplu deneysel desen kullanılmıştır. Bu çalışmanın örneklem grubunda 2018-2019 eğitim öğretim yılında İstanbul İli Üsküdar İlçesindeki bir İmam Hatip Lisesi’nde 11.sınıfa devam eden 10 deney 10 kontrol olmak üzere toplam 20 kız öğrenci yer almaktadır. Deney ve kontrol grubuna ön test ve son test olarak Frost Çok Boyutlu Mükemmeliyetçilik Ölçeği’nin Hata yapma Endişesi alt boyutu ve Akademik Erteleme Ölçeği uygulanmıştır. Manevi Yönelimli Bilişsel Davranışçı Psikolojik Danışma çalışması 8 hafta boyunca 90 dakikalık oturumlar şeklinde gerçekleşmiştir. Deney ve kontrol grubunun ön-test ve son-test puanları arasında bir fark olup olmadığını belirlemek amacıyla Non-parametrik Mann-Whitney U testi yapılmıştır. Deney grubunun başarısızlık korkusu ve akademik erteleme ön-test ve son-test puanları ile kontrol grubunun başarısızlık korkusu ve akademik erteleme ön-test ve son-test puanları arasında anlamlı bir fark olup olmadığını test etmek amacıyla Non-parametrik Wilcoxon İşaretli Sıralama testinden yararlanılmıştır. Araştırma sonucunda Manevi Yönelimli Bilişsel Davranış̧̧ı Grupla Psikolojik Danışmanlık Çalışmasının başarısızlık korkusu ve akademik erteleme üzerinde etkili olduğu bulunmuş, sonuçlar tartışılmıştır.

Anahtar Kelimler

Başarısızlık korkusu, Akademik erteme, Maneviyat, Bilişsel davranışçı yaklaşım

1 Correspondence to: Serra Dinç, University of Health Sciences, Istanbul, Turkey. E-mail: serra.dinc@sbu.edu.tr 2 Department of Educational Sciences, Marmara University, Istanbul, Turkey. E-mail: halileksi@marmara.edu.tr

Citation: Dinç, S. \& Ekşi, H. (2019). A psychological counseling study on fear of failure and academic procrastination with a spiritually oriented cognitive behavioral group. Spiritual Psychology and Counseling, 4, 219-235. http://dx.doi.org/10.37898/spc.2019.4.3.85 
Avoidance of failure due to fear and the shame of failure can be explained as fear of failure (Caraway, Tucker, Reinke, \& Hall, 2003; Elliot \& Thrash, 2004). It also refers to the situation where a person feels threatened and anxious about failing (Conroy, Poczwardowski, \& Henschen, 2001) because the individual has learned to associate failure with negative results (Conroy, Kaye, \& Fifer, 2007). A person who fails considers the failure to be a constant threat, thinking that it will cause embarrassment. For this reason, negative thoughts and beliefs about one's self increase the fear of failure. When people evaluate themselves as a result of failure, they view themselves as less important. They think that others will always evaluate them negatively and they will fall into disfavor, thus increasing their concerns about the future (Conroy, 2004; Conroy, Willow, \& Metzler, 2002). Fear of failure is also a result of perfectionism (Conroy, Kaye, \& Fifer, 2007). Symptoms of perfectionism such as excessive focus on the future, the all-or-nothing principle, and being the best or not doing the work sets high standards for the individual and creates the fear of failure (Ellis \& Harper, 1975; Şirin, 2011; Tran, 2000). Individuals with a fear of failure expect clarity about being successful in their situation. This is different from the need to be successful. A person who needs to be successful doesn't necessarily seek a guarantee of success (Cüceloğlu, 2019). Accordingly, the need for success can be expressed as intrinsic motivation and fear of failure as an external source of motivation (Uyulgan \& Akkuzu, 2014).

A person with a fear of failure has low self-efficacy. Therefore, the possibility of setting and working on goals decreases. This prevents efficiency levels from increasing. In short, it turns into a compulsive cycle (Caraway, Tucker, Reinke, \& Hall, 2003). People in this cycle think they don't have enough skills to cope with the situation they are in, which leads to irrational thoughts that they will fail. As a result, delays in their duties and responsibilities may occur. This situation also applies to students who do not consider themselves sufficient at fulfilling their academic duties and responsibilities. Students who consider themselves inadequate and who fear failing may exhibit procrastination behaviors (Chow, 2011; Knaus, 1998; Waschle, Allgaier, Lachner, Fink, \& Nückles, 2014). Students' failure to even complete their given academic duties and responsibilities on time without a rational explanation can be defined as academic procrastination (Balkıs \& Duru, 2012; Kağan, 2009). Examples of this are the failure to deliver assignments on time, delays in preparing for examinations, and plans that fail to match behaviors (Senecal, Julien, \& Guay, 2003; Solomon \& Rothblum, 1984). Solomon and Rothblum (1984) claimed that, although many reasons exist for academic procrastination, the main reason is fear of failure. Their research examined the frequency of academic procrastination and concluded students to exhibit procrastination behaviors because students think they are unable do their tasks the way they want. Many studies are found to suggest that students who are anxious about failing procrastinate academically by delaying their 
duties (Balk1s, 2006; Uzun Özer, 2005; Fatimah, Lukman, Khairudin, Shahrazad, \& Halim, 2011; Kandemir, Çakır, Özbay, Palanc1, \& Çalışkan, 2009; Middleton \& Midgley, 1997; Ozer \& Altun, 2011; Uzun Ozer \& Topkaya, 2005).

As stated above, irrational beliefs, perfectionism, and low self-efficacy lead to fear of failure while similarly negative automatic thoughts and perfectionist thinking lead to academic procrastination (Flett, Stainton, Hewitt, Sherry, \& Lay, 2012). In other words, irrational ideas that cause fear of failure also cause academic procrastination (Haghbin, McCaffrey, \& Pychyl, 2012). Individuals who postpone any responsibility are worried about being unsuccessful and being evaluated for their own performance (Ferrari, Jonhson, \& McCown, 1995). Cognitive studies on the causes of procrastination have shown that perfectionism, fear of failure, cognitive distortions, negative automatic thoughts, and non-rational thoughts lead to academic procrastination (Beswick, Rothblum, \& Mann, 1988; Flett, Stainton, Hewitt, Sherry, \& Lay, 2012; Kağan; Solomon and Rothblum, 1984).

Cognitive behavioral therapy, which focuses on the specific thoughts and behaviors that result from errors in the cognitive processes in a person's life and aims to change them, is a method that can be studied through problems such as perfectionism and fear of failure. Several studies are found to suggest that cognitive behavioral therapy is effective on fear of failure and academic procrastination (Kağan, 2010; Toker \& Avc1, 2015; Wang et al., 2017). This study conducts a spiritually oriented cognitive behavioral therapy (CBT). Spirituality is a value that supports individual understanding of life and the creation of ultimate goals (Oginska-Bulik, 2013). Spirituality, which is a completely individual concept, can include religious values as well as be evaluated separate from religion (Polanski, 2013). In terms of psychological counseling, the use of spirituality as a coping method serves to make the therapeutic process more concrete (Kasapoğlu, 2017). In recent years, various practices have been implemented by adding spiritually oriented techniques to many types of therapy (Breitbart, 2012; Elkins, 2005; Harris, 2000; Hoffman, 2004; Robbins, 2014; Scott Richards, Berrett, Hardman, \& Eggett, 2006). Several reasons exist as to why spirituality is used in therapy sessions. The biggest factor can be shown as the client who brings a spiritual problem to the session. A spirituality-based approach may be necessary to solve this problem. At the same time, spirituality can either be an obstacle or a contribution to the solution of the client's problem. Psychotherapy also has a spiritual dimension, and integrating any spiritual approach into the therapy technique being used can make the process more efficient (Pargament, 2007).

However, if a spiritual-oriented therapy technique is to be used, certain ethical responsibilities need to be considered. First of all, spiritual orientations can be integrated with the client's own consent in order to avoid any imposition on the client. 
The client may have negative attitudes regarding the spiritual techniques to be used, even where the client's request is concerned. For this reason, past and present stories about the client's detailed spiritual thoughts and behaviors should be taken in the first session. Another responsibility is that the therapist implementing this should receive supervision from another specialist in this field on how to use spiritual orientation (Post \& Wade, 2009; Vasegh, 2007).

Spiritually oriented CBT involves the integration of various spiritual techniques without making any changes in the secular CBT formulation. These techniques can be exemplified as: providing a reevaluation of irrational thoughts using various religious texts; praying for a variety of the behavioral tasks used to reinforce cognitive tasks; submitting worship or various other religious bibliotherapy recommendations; ensuring that these behavioral tasks are recorded; having relaxation exercises using some spiritual terms; supporting cognitive reassessment using spiritual terms such as forgiveness, acceptance, and thankfulness, having the client recognize and cope with spiritual cognitive distortions such as guilt and hopelessness caused by a number of religious reasons (Azhar, Varma, \& Dharop, 1994; Barrera, Zeno, Bush, Barber, \& Stanley, 2012; Bristow-Braitman, 1995; Purdon \& Clark, 2013).

Many studies have been conducted on integrating spiritual-oriented therapy techniques into CBT, which is an effective method in individual and group counseling sessions. These studies have included individual interviews as well as group intervention programs. Spiritually oriented cognitive behavioral therapy studies have been conducted over various problems such as affective disorders, anxiety disorders, trauma, cancer, and addiction (Azhar \& Varma, 2000; Cohen, Mannariono, Deblinge, \& Berliner, 2009; Ebrahimi, Neshatdoost, Mousavi, Asadollahi, \& Nasiri, 2013; Good, 2010; Hawkins, Tan, \& Turk, 1999; Rosmarin, Auerbach, Bigda-Peyton, Bjorginsson, \& Levendusky, 2011; Tan \& Johnson, 2005).

Cognitive behavioral psychological counseling is thought to minimize the reasons underlying fear of failure such as perfectionism, low self-efficacy, and irrational thoughts. Academic procrastination is seen in students with fear of failure who are worried about the evaluation of their own performances. The therapeutic study of irrational thoughts and cognitive distortions about failure is thought to lessen academic procrastination. Adding spirituality to interventions makes the process more efficient as spirituality is one of the dimensions of psychotherapy; it also makes dealig with problems during psychological counseling easier and the process more efficient. For this reason, the use of spiritually oriented cognitive behavioral psychological counseling on people with fear of failure and academic procrastination is considered able to help reduce the factors that cause them. However, when examining the literature, the lack of spiritually oriented cognitive behavioral psychological 
counseling studies in a Turkish sample is notable. Not even a spiritually oriented CISbased experimental study is found on fear of failure and academic procrastination. When examining the psychological counseling studies conducted especially in high schools, spiritually oriented psychological counseling studies are not seen as part of the literature. In order to fill this gap, developing group counseling programs is important. For this reason, the aim is to prepare, implement, and test the effectiveness of psychological counseling with 8-week group study based on the spiritually oriented cognitive behavioral approach in order to reduce high school students' fear of failure and hence their academic procrastination.

\section{Method}

\section{Research Model}

This study uses a pre-test post-test control group experimental design to determine whether spiritually oriented cognitive behavioral group and psychological counseling is effective on high school students' fear of failure and academic procrastination. The independent variable of the study is the group counseling program and the dependent variables are fear of failure and academic procrastination levels.

\section{Study group}

The sample group of this study consists of 20 female students (10 experimental and 10 controls) attending 11th grade at an Imam Hatip High School in the Üsküdar District of Istanbul during the 2018-2019 academic year. Experimental and control group students have been selected using the purposeful sampling method. They were chosen on a volunteer basis among the 11th-grade students who are considered to experience fear of failure as a result of the observations of teachers and administrators in the school.

\section{Data Collection Tools}

Frost's Multidimensional Perfectionism Scale. The atychiphobia subscale of the Multidimensional Perfectionism Scale developed by Frost, Marten, Lahart, and Rsenblate (1990) and adapted to Turkish by Kağan (2011) has been used to determine the level of participants' fear of failure. The scale consists of 35 items; the atychiphobia sub-dimension consists of 8 items. Cronbach's alpha of reliability for the scale is .91 , and the alpha of reliability for the sub-dimension is .85 . The test rereliability coefficient of the scale is .82 (Kağan, 2011).

Academic Procrastination Scale. The scale consists of 19 items and two factors and was developed by Çakıcı (2003). The factors include procrastination and regular 
study habits. Cronbach's alpha of reliability for the scale has been calculated as .92 . Cronbach's alpha of reliability for the first factor of the scale is .89 and for the second factor, .84 . The test-retest correlation coefficient is .89 . The test-retest reliability coefficient of the scale has been calculated as .80 for the first factor and .82 for the second factor (Çakıcı, 2003).

\section{Data Analysis}

The data in this study have been analyzed with the package program SPSS 21. The non-parametric Mann-Whitney $U$ test has been performed to determine whether a difference exists between pretest and posttest scores for the experimental and control groups. As the number of participants in the experimental and control groups is less than 30 and not distributed normally, the Mann-Whitney U and Wilcoxon signed-rank tests, which are non-parametric statistical analyses, have been used (Büyüköztürk, 2007). The non-parametric Wilcoxon signed-rank test is used to test whether a significant difference exists between the experimental group's fear of failure and academic procrastination pre-test and post-test scores and the control group's fear of failure and academic procrastination pre-test and post-test scores.

\section{The Research Process}

The cognitive behavioral-based group counseling program in this study has been developed based on fear of failure. In spiritually oriented CBT studies, standard CBT practices are performed in each session, and if spiritual practices are thought able to help the participants, spiritual practices can be integrated with the participants' approval (Summermatter, 2017). For this reason, cognitive behavioral-based spiritual techniques have been added to the cognitive behavioral approach group counseling, which consists of eight 90-minute sessions. Examples of spiritually oriented CBT in the literature have been examined for determining which spiritual techniques to use (Azhar, Varma, \& Dharop, 1994; Barrera, Zeno, Bush, Barber, \& Stanley, 2012; Bristow-Braitman, 1995; Purdon \& Clark, 2013; Walker, Reese, Hughes, \& Troskie). The author, a clinical psychologist and Ph.D. student in guidance and psychological counseling, developed a program and presented it to two academicians specialized in the field for evaluation. As a result of the given feedback, changes were made and the final version was formed. A draft of the content of the program was prepared and presented to the administration in the school where the study will be implemented. After the approval of the administration and teachers, the program got the approval of students and parents. After obtaining permission from the district branch of the Ministry of National Education, the program was applied to the experimental group. No intervention was made to the control group during this period. Frost's Multidimensional Perfectionism Scale and the Academic Procrastination Scale were 
applied to the experimental and control groups before and after the psychological counseling study.

\section{Operation}

The process of psychological counseling with the group is summarized as follows. In the first session, a meeting is held and the group rules are determined. Brainstorming was made on the concept of success and the participants' cognitive and spiritual aspects were determined. The second session begins by giving a psycho-educational lesson on anxiety, fear, fear of failure, and its causes. Exercises are done on recognizing and normalizing thoughts and feelings and self-awareness of past achievements; examples from the Prophet's life were presented as motivational reinforcement, and spiritually based relaxation exercises were practiced. The third session aims to help them realize their own distortions by recognizing automatic thoughts about fear of failure and introducing general and spiritual cognitive distortions using the techniques of direct questions, Socratic questioning, and directed discovery. The fourth session explains the relationships among emotion, thought, and behavior with the aim of using religious texts to show that perception is the basis for the causes of fear of failure and to confute the spiritual cognitive distortions they had noticed before as well as other cognitive distortions about the environmental factors they think cause fear of failure using the double standard technique and Socratic inquiry and to make them notice their perfectionist attitudes.

A religious text is given as a reading assignment to reinforce awareness of their distortions and how to counter them. The fifth session aims to teach rational alternative thoughts, to recognize emotions more clearly, to grasp the connection between thought and emotion, to identify logical and irrational thoughts about fear of failure, and to share a prayer and hadith in order to realize the concept of trust using the alternative thinking and empty chair techniques. In order to spiritually reinforce the concept of rational and irrational thoughts about failure fears, alternative thinking and encouragement techniques have been used, such as "Allah is with those who are patient" and "Allah rewards those who struggle." The sixth session conducts a benefit-loss analysis conducted and shares anecdotes describing the difficulties and eases encountered on the way to success, rendering the theme of surrendering to God after doing one's best by fulfilling responsibilities. The seventh session uses various activities and games to develop cognitive and spiritual coping skills and to reinforce the concept of surrender (acceptance). The eighth and final session summarizes all previous sessions and discusses what the group has noticed about themselves during the psychological counseling study; they share what the study has contributed to them and the benefits associated with using them in daily life. The session is concluded by wishing them the best. 


\section{Results}

In this part of the study, fear of failure in the control and experimental groups and the findings on their arithmetic means and standard deviations for the academic procrastination pretest and posttest results are presented in Table 1 in line with the stated hypotheses.

Table 1

Findings on the Pre-tests and Posttests Arithmetic Means and Standard Deviations Scores of the Control and Experimental Groups

\begin{tabular}{lcccccc}
\hline & \multicolumn{3}{c}{ Pre Test } & \multicolumn{3}{c}{ Post Test } \\
\cline { 2 - 7 } & $\mathrm{N}$ & $\mathrm{x}$ & $\mathrm{sd}$ & $\mathrm{N}$ & $\mathrm{x}$ & $\mathrm{sd}$ \\
\hline Fear of Failure Experimental Group & 10 & 15.30 & 5.25 & 10 & 11.30 & 3.83 \\
Academic Procrastination Experimental & 10 & 53.30 & 7.30 & 10 & 51.20 & 7.56 \\
Group & & & & & & \\
Fear of Failure Control Group & 10 & 15.80 & 5.15 & 10 & 15.20 & 3.83 \\
Academic Procrastination Control Group & 10 & 51.90 & 10.18 & 10 & 55.50 & 7.02 \\
\hline
\end{tabular}

Table 2 presents the results from the Mann-Whitney $U$ test that has been performed to test whether the experimental and control groups' pretest scores for the perfectionism (fear of failure) scale differ.

Table 2

The Results of the Mann-Whitney U Test for Pre-tests Scores of Fail of Failure Experimental and Control Groups

\begin{tabular}{llcccc}
\hline & $\mathrm{N}$ & Mean Rank & Sum of Rank & $\mathrm{U}$ & $\mathrm{Z}$ \\
\hline Experimental Group & 10 & 9.85 & 98.50 & & \\
Control Group & 10 & 11.15 & 111.50 & 43.50 & -.495 \\
Total & 20 & & & & \\
\hline
\end{tabular}

No significant difference exists between the fear of failure scores for the experimental and control groups in Table $2(z=-0.495 ; p=.621 ; p>.05)$. In other words, participants from both groups had equal level of fear of failure prior to the group counseling.

Table 3 presents the results from the Mann-Whitney $U$ test that has been performed to test whether the experimental and control groups' pretest scores from the academic procrastination scale differ.

Table 3

The Results of the Mann-Whitney U Test for Pre-tests Scores of Academic Procrastination Experimental and Control Groups

\begin{tabular}{lccccc}
\hline & $\mathrm{N}$ & Mean Rank & Sum of Rank & $\mathrm{U}$ & $\mathrm{Z}$ \\
\hline Experimental Group & 10 & 11.10 & 111.00 & & \\
Control Group & 10 & 9.90 & 99.00 & 44.00 & -.45 \\
Total & 20 & & & & \\
\hline
\end{tabular}

No significant difference exists between the academic procrastination scores for the experimental and control groups, as given in Table $3 . z=-.45 ; p=.65 ; p>.05)$. In other words, both groups of participants had equal academic procrastination levels before the group counseling. 
The Wilcoxon signed-rank test has been applied to test the hypothesis that the experimental group's posttest perfectionism scores would decrease compared to their pre-test scores; Table 4 presents the results.

Tablo 4

The Results of The Wilcoxon Signed Rank Test for Pretest-Posttest Scores of Fail of Failure Experimental Group

\begin{tabular}{lcccc}
\hline & $\mathrm{N}$ & Sum of Rank & Mean Rank & $\mathrm{Z}$ \\
\hline Negative Rank & 10 & 4.50 & 36 & -2.52 \\
Positive Rank & 0 & - & - & - \\
Ties & 0 & - & & \\
Total & 10 & & & \\
\hline
\end{tabular}

According to the results from the Wilcoxon signed-rank test performed on the experimental group as given in Table 4, a statistically significant difference exists between their pretest and posttest fear of failure scores $(z=-2.52, p=.012, p<.05)$. In other words, the experimental group's fear of failure scores decreased after the group counseling.

In order to test the hypothesis that the experimental group's posttest academic procrastination scores will decrease compared to the pre-test results, the Wilcoxon signed-rank test has been applied; Table 5 presents the results.

Tablo 5

The Results of The Wilcoxon Signed Rank Test for Pretest-Posttest Scores of Academic Procrastination Experimental Group

\begin{tabular}{lcccc}
\hline & N & Sum of Rank & Mean Rank & Z \\
\hline Negative Rank & 7 & 4.00 & 28 & -2.37 \\
Positive Rank & 0 & - & - & - \\
Ties & 3 & - & & \\
Total & 10 & & & \\
\hline
\end{tabular}

According to the results from the Wilcoxon Rank Test performed on the experimental group as given in Table 5, a statistically significant difference exists between the experimental group's pretest and posttest academic procrastination scores $(z=-2.37, p=.017, p<.05)$. In other words, their academic procrastination scores decreased after group counseling.

In order to test the hypothesis that no statistically significant difference exists between the control group's pretest and posttest scores for fear of failure, the Wilcoxon signed-rank test has been applied; the results are presented in Table 6. 
Tablo 6

The Results of The Wilcoxon Signed Rank Test for Pretest-Posttest Scores of Fail of Failure Control Group

\begin{tabular}{lcccc}
\hline & $\mathrm{N}$ & Sum of Rank & Mean Rank & $\mathrm{Z}$ \\
\hline Negative Rank & 6 & 5.5 & 22.00 & -.56 \\
Positive Rank & 3 & 3.5 & 14.00 & - \\
Ties & 1 & - & & \\
Total & 10 & & & \\
\hline
\end{tabular}

According to the results from the non-parametric Wilcoxon signed-rank test performed on the control group as given in Table 6, no statistically significant difference exists between their pretest and posttest fear of failure scores $(z=-0.56, p=.572, p>.05)$.

In order to test the last hypothesis of the study, which is that no statistically significant difference exists between the control group's pretest and posttest academic procrastination scores, the Wilcoxon signed-rank test has been applied; Table 7 presents the results.

Tablo 7

The Results of The Wilcoxon Signed Rank Test for Pretest-Posttest Scores of Academic Procrastination Control Group

\begin{tabular}{lcccc}
\hline & $\mathrm{N}$ & Mean Rank & Sum of Rank & $\mathrm{z}$ \\
\hline Negative Rank & 3 & 3.83 & 11.50 & \\
Positive Rank & 7 & 6.21 & 43.50 & -1.63 \\
Ties & 0 & - & - & \\
Total & 10 & & & \\
\hline
\end{tabular}

According to the results from the non-parametric Wilcoxon signed-rank test performed on the control group as given in Table 7, no statistically significant difference is present between the control group's pretest and posttest academic procrastination scores $(z=-1.63, p=.102, p>.05)$.

Table 8 presents the results from the Mann-Whitney $U$ test, which has been conducted to test the hypothesis that the experimental and control groups' posttest scores from the perfectionism (fear of failure) scale will be different.

Table 8

The Results of the Mann-Whitney U Test for Post-tests Scores of Fail of Failure Experimental and Control Groups

\begin{tabular}{llcccc}
\hline & $\mathrm{N}$ & Mean Rank & Sum of rank & $\mathrm{U}$ & $\mathrm{Z}$ \\
\hline Experimental Group & 10 & 7.75 & 77.50 & & \\
Control Group & 10 & 13.25 & 132.50 & 22.50 & -2.11 \\
Total & 20 & & & & \\
\hline
\end{tabular}

A significant difference has been found between the experimental and control groups' posttest scores for fear of failure, as given in Table $8(z=-2.11, p=.034$; $p<.05)$. In other words, the experimental group's posttest scores for fear of failure are significantly lower than the control group's posttest scores. 
Table 9 presents the results from the Mann-Whitney U test, which has been performed to test the hypothesis that the experimental and control groups' posttest scores from the academic procrastination scale will be different.

Table 9

The Results of the Mann-Whitney U Test for Post-tests Scores of Academic Procrastination Experimental and Control Groups

\begin{tabular}{lccccc}
\hline & $\mathrm{N}$ & Mean Rank & Sum of Rank & $\mathrm{U}$ & $\mathrm{Z}$ \\
\hline Experimental Group & 10 & 8.50 & 85.00 & & \\
Control Group & 10 & 12.50 & 125.00 & 30.00 & -1.51 \\
Total & 20 & & & & \\
\hline
\end{tabular}

According to the results given in Table 9, no significant difference exists between the experimental and control groups' posttest scores for academic procrastination $(z$ $=-1.51, p=.129 ; p>.05)$. In other words, the hypothesis that the experimental and control groups' post-test scores for academic procrastination would differ has not been supported.

\section{Discussion}

This study has aimed to test the effectiveness of an 8-week group psychological counseling program based on the spiritually oriented cognitive behavioral approach, which was developed to reduce high school students' fear of failure and, hence, their academic procrastination levels. The results are given below and discussed. At the beginning of the study, no significant difference was found between the experimental and control groups' fear of failure and academic procrastination scale scores. Psychological counseling was applied to the experimental group and no intervention was made on the control group.

The obtained results showed the psychological counseling with a spiritually oriented cognitive behavior group to have reduced high school students' fear of failure and academic procrastination levels. In addition, no significant difference was found between the control group's posttest and pretest levels for fear of failure fear and academic procrastination; the experimental group's posttest scores for fear of failure were lower than the control group's posttest scores for fear of failure. This indicates the group counseling had been effective. However, no significant difference was found between the experimental and control groups' posttest procrastination scores; the control group's posttest academic procrastination scores increased.

Students who had expressed their expectations in the first session of the group study stated that they had participated in this study because they expected their fear of failure to decrease. When examining the cognitive and spiritual states underlying fear of failure, they have been revealed to think that they should not make mistakes because of their responsibilities toward themselves, their families, society, all Muslims, and 
Allah in this life. Therefore they thought they wouldn't make mistakes. They were seen to always think that they had to see themselves as inadequate and thus would move to the positions they wanted to have in the future. When asked what had changed in themselves and what they had gained at the end of the psychological counseling with the spiritually oriented cognitive behavioral group, the group expressed initially having had concerns about their own competences but now realized that they had taken many actions counter to their responsibilities so far; they also stated that, even if they were to make mistakes, as long as they also made goals and plans for the future, they could achieve their goals because they trust in God. They also stated that recalling prayers and the fact that prophets faced difficulties in life and had somehow been successful to have been motivating to them.

Studies on fear of failure have shown perfectionism to be present at its base; therefore this results in trying to do the best and being ashamed of themselves, considering themselves worthless, worrying about being seen as worthless, and feeling a lack of self-efficacy when they don't do their best (Caraway, Tucker, Reinke, \& Hall, 2003; Conroy, Kaye, \& Fifer, 2007; Conroy, Willow, \& Metzler, 2002; Tran, 2000). Cognitive behavioral group psychological counseling has been tested and shown to be effective in many studies in which it reduces the negative thinking and perfectionism that cause fear of failure (Arpin-Cribbie, Irvine, \& Ritvo, 2012; Handley, Egan, Kane, \& Rees, 2015; Y1ldız, 2018). Kağan (2009) applied cognitive behavioral therapy in his study on perfectionism and fear of failure to eight professional volleyball and basketball players; as a result, their levels of perfectionism and fear of failure decreased. Various studies have revealed the main reasons for academic procrastination, which is another variable in the current study, to be a self-perception of inadequacy and fear of failure (Haghbin, McCaffrey, \& Pychyl, 2012; Solomon \& Rothblum, 1984; Waschle, Allgaier, Lachner, Fink, \& Nückles, 2014). One study on academic procrastination in university students (Wang et al., 2017) showed academic procrastination to occur due to problems with selfefficacy and psychological flexibility; these problems decreased more effectively with acceptance stability therapy more than time management. Online and face-toface cognitive behavioral therapy was also administered to 100 students who had applied to a university health center in order to reduce academic procrastination. Both methods were shown to reduce academic procrastination (Rozental, Forsström, Nilsson, Rizzo, \& Carlbring, 2014).

Spirituality, a dimension of psychotherapy, is seen to enrich the therapies it is integrated with as well as to increase their effectiveness (Cole \& Pargament, 1999; Snodgrass, 2009). In addition, spirituality has been found to be effective for coping with negative emotions (Rosmarin, Auerbach, Bigda-Peyton, Björgvinsson, \& Levendusky, 2011). Many studies are found in the literature on the effectiveness 
of spiritually oriented cognitive behavioral therapies. In a study conducted with 59 depression patients, religiously oriented cognitive behavioral therapy was applied to the experimental group and cognitive behavioral therapy without religious orientation was applied to the control group. At the end of the study, the depression levels of those who had received religiously oriented cognitive behavioral therapy were lower than those who had not (Propst, Ostrom, Watkins, Dean, \& Mashburn, 1992). A decrease in religious obsessions was found in 50 OCD patients with religious obsessions after 10 weeks of religiously oriented cognitive behavioral therapy (Akuchekian, Jamshidian, Maracy, Almasi, \& Jazi, 2011).

Psychological counseling studies with spiritually oriented cognitive behavioral group are seen in the literature mostly to be related to perfectionism, low self-efficacy, and the irrational thoughts that cause it rather than fear of failure. As a result of a cognitive-behavioral psychological counseling study conducted with a spiritually oriented group of 15 Mormon students, a decrease was observed in the students' perfectionist levels (Richards, Owen, \& Stein, 1993).

One limitation of this study is the sample group's fear of failure and academic procrastination scores were not very high. Another limitation is the group had been determined as a result of the observations of school administrators and teachers. Measuring the fear of failure and academic procrastination scores of all the students in a school and then selecting at random those with higher scores would instead be more appropriate for other studies.

The findings obtained in this study have been found to be consistent with the literature; psychological counseling with a spiritually oriented cognitive behavioral group has had an effect on fear of failure and, as a consequence, academic procrastination. In this way, the study is considered to have filled a gap both academically and practically. Based on this, the result has emerged that spirituality can be integrated with a CBT-oriented group study in the direction of students demands toward fear of failure and academic procrastination, which are common problems in secondary and higher education. Future studies should observe and determine both the spiritual and cognitive deficiencies students have on this subject using quantitative and qualitative methods, and then these should be re-shaped and applied in accordance with their needs. This provides the opportunity to explore more in-depth and yield more effective results. In addition, planning a study to include not only students but also parents and teachers may lead to faster resolutions to these problems. 


\section{References}

Akuchekian, S., Jamshidian, Z., Maracy, M. R., Almasi, A., \& Jazi, A. H. D. (2011). Effectiveness of Religious Cognitive-Behavioral Therapy on Religious Oriented Obsessive Compulsive Disorder and its Co-morbidity. Journal of Isfahan Medical School, 28(114).

Arpin-Cribbie, C., Irvine, J., \& Ritvo, P. (2012). Web-based cognitive-behavioral therapy for perfectionism: A randomized controlled trial. Psychotherapy Research, 22(2), 194-207

Azhar, M. Z., Varma, S. L., \& Dhorap, A. S. (1994). Religious psychotherapy in anxiety disorder patients. Acta Psychiatrica Scandinavica, 90, 1-3.

Azhar, M. Z., \& Varma, S. L. (2000). Mental Illness and Its Treatment in Malaysia. In I. AlIssa (Ed.), Al-Junūn: Mental illness in the Islamic world (pp. 163-186). Madison, CT, US: International Universities Press, Inc.

Balkıs, M. (2006). Öğretmen Adaylarının Davranıslarındaki Erteleme Eğiliminin, Karar Verme Tarzları Ile Iliskisi. (Yayınlanmamıs Doktora Tezi). İzmir: Dokuz Eylül .niversitesi, Eğitim Bilimleri Enstitüsü.

Balkıs, M. ve Duru, E. (2010). Akademik Erteleme Eğilimi, Akademik Başarı İlişkisinde Genel ve Performans Benlik Saygısının Rolü, Pamukkale Üniversitesi Eğitim Fakültesi Dergisi, 27, 159-170.

Barrera, T. L., Zeno, D., Bush, A. L., Barber, C. R., Stanley, M. A. (2012). Integrating religion and spirituality into treatment for late-life anxiety: Three case studies. Cognitive and Behavioral Practice, 19, 346-358.

Berber Çelik, Ç., ve Odacı, H. (2015). Akademik erteleme davranışının bazı kişisel ve psikolojik değişkenlere göre açıllanması. Hacettepe Üniversitesi Eğitim Fakültesi Dergisi (HU Journal of Education), 30(3), 31-47.

Beswick, G., Rothblum, E. D., \& Mann, L. (1988). Psychological antecedents of student procrastination. Australian Psychologist, 23, 207-217.

Breitbart, W. (2002). Spirituality and meaning in supportive care: spirituality-and meaning centered group psychotherapy interventions in advanced cancer. Supportive care in cancer, 10(4), 272280.

Bristow $\square$ Braitman, A. (1995). Addiction Recovery: $12 \square$ Step Programs and Cognitive $\square$ Behavioral Psychology. Journal of Counseling \& Development, 73(4), 414-418.

Büyüköztürk, Ş. (2007). Deneysel Desenler. Ankara: Pegem Akademi.

Caraway, K., Tucker, C. M., Reinke, W. M., \& Hall, C. (2003). Self $\square$ efficacy, goal orientation, and fear f failure as predictors of school engagement in high school students. Psychology in the Schools, 40(4), 417-427.

Chow, H. P. H. (2011). Procrastination among undergraduate students: Effects of emotional intelligence, school life, self-evaluation, and self- efficacy. Alberta Journal of Educational Research, 57(2), 234-240.

Cohen, J. A., Mannarino, A. P., Deblinger, E., \&amp; Berliner, L. (2009). Cognitive-Behavioral Therapy for Children and Adolescents. In E. B. Foa, T. M. Keane, M. J. Friedman, \&amp; J. A. Cohen (Ed.) Effective treatments for PTSD: Practice guidelines from the International Society for Traumatic Stress Studies (s. 223-244). N New York, NY: Guilford.

Cole, B., \& Pargament, K. I. (1999). Re-creating your life: A spiritual: Psychotherapeutic intervention for people diagnosed with cancer. Psycho-Oncology, 8, 395-407. 
Conroy, D. E., Kaye, M. P., \& Fifer, A. M. (2007). Cognitive links between fear of failure and perfectionism. Journal of Rational-Emotive \& Cognitive-Behavior Therapy, 25(4), 237-253.

Conroy, D. E., Poczwardowski, A., \& Henschen, K. P. (2001). Evaluative criteria and consequences associated with failure and success for elite athletes and performing artists. Journal of Applied Sport Psychology, 13, 300322.

Cüceloğlu, D. (2019). Insan ve davranışı (37. bs). İstanbul: Remzi Kitabevi

Çakıcı, D. Ç. (2003). Lise ve Üniversite Öğrencilerinde Genel Erteleme Ve Akademik Erteleme Davranışının İncelenmesi (Yayımlanmamış yüksek lisans tezi). Ankara Üniversitesi, Eğitim Bilimleri Enstitüsü, Ankara.

Ebrahimi, A., Neshatdoost, H. T., Mousavi, S. G., Asadollahi, G. A., \& Nasiri, H. (2013).

Controlled randomized clinical trial of spirituality integrated psychotherapy, cognitive behavioral therapy and medication intervention on depressive symptoms and dysfunctional attitudes in patients with dysthymic disorder. Advanced biomedical research, 2.

Ellis, A.E \& Harper, R.A. (1975). A New Guide to Raitonal Living. Hollywood: Willshire.

Elkins, D. N. (2005). A Humanistic Approach to Spiritually Oriented Psychotherapy. In L.E. Sperry \& E.P. Shafranske (Eds.), Spiritually Oriented Psychotherapy (pp.131-151). Washington, DC: APA

Fatimah, O., Lukman, Z.M., Khairudin, R., Shahrazad W. S. \& Halim, W, F. (2011). Procrastination's Relation with Fear of Failure, Competence Expectancy and Intrinsic Motivation. Pertanika J. Soc. Sci. \& Hum. 19 (S): $123-127$

Ferrari, J. R., Jonhson, J. L., \& McCown, W. G. (1995). Procrastination and task avoidance: Theory, research and treatment. New York: Plenum.

Flett, G.L., Stainton, M. Hewitt, P.L., Sherry, S.B., \& Lay, C. (2012). Procrastination automatic thoughts as a personality construct: An analysis of the procrastinatory cognitions inventory. Journal of Rational-Emotive and Cognitive-Behavior Therapy, 30(4), 223-236.

Haghbin, M., McCaffrey, A., \& Pychyl, T. A. (2012). The complexity of the relation between fear of failure and procrastination. Journal of Rational-Emotive and Cognitive-Behavior Therapy, 30(4), 249-263.

Handley, A. K., Egan, S. J., Kane, R. T., \& Rees, C. S. (2015). A randomised controlled trial of group cognitive behavioural therapy for perfectionism. Behaviour Research and Therapy, 68, $37-47$.

Harris, E. S. (2000). God, Buber and the practice of gestalt therapy. Gestalt Journal, 23(1), 39-62.

Hawkins, R.S., Tan, S.Y., \& Turk, A. A. (1999). Secular versus Christian inpatient cognitive behavioral therapy programs: Impact on depression and spiritual well-being. Journal of Psychology and Theology, 274, 309-318.

Hoffman, L. (2004). Cultural constructions of the God image and God concept: Implications for culture, psychology, and religion. In Joint Meeting of the Society for the Scientific Study of Religion/Religious Research Association, Kansas City, MO.

Good, J. J. (2010). Integration of spirituality and cognitive-behavioral therapy for the treatment of depression (Doctoral dissertation), Philadelphia College of Osteopathic Medicine Department of Psychology.

Kağan, S. (2006). Bilişsel Davranış̧̧ı Terapiye Dayalı Mükemmeliyetçilik Eğitiminin Sporcuların Mükemmeliyetçilik, Başarı Güdüsü Ve Başarısızlık Korkusuna Etkisi. (Yayımlanmamış 
Doktora Tezi). Ankara Üniversitesi Eğitim Bilimleri Enstitüsü. Ankara.

Kağan, M. (2009). Determining the variables which explain the behavior of academic procrastination in university students. Ankara University J. Fac. Educ. Sci., 42(2): 113-128.

Kağan, M. (2010). Akılcı Duygusal Davranışsal Yaklaşıma Dayalı Akademik Erteleme Davranışını Önleme Programının Etkililiğinin Değerlendirilmesi. (Yayınlanmamış doktora tezi). Ankara Üniversitesi, Ankara.

Kagan, M. (2011). Frost Çok Boyutlu Mükemmelliyetçilik Ölçeginin Türkçe formunun psikometrik özellikleri/Psychometric properties of the Turkish version of the Frost Multidimensional Perfectionism Scale. Anadolu Psikiyatri Dergisi, 12(3), 192.

Kandemir, Çakır, Özbay, Palancı ve Çalışkan, (2009). Öğrencilerin kaygı düzeylerinin, mükemmeliyet.i kişilik özellikleri, başarı amaç oryantasyonu, akademik erteleme davranışları, akademik benlik saygısı ve başarısızlık korkusu ile yordanması. X. Ulusal Psikolojik Danışma ve Rehberlik Kongresi’nde sunulan bildiri, 21- 22-23 Ekim, Adana.

Kasapoğlu, F. (2017).Terapötik Süreçte Maneviyatın Değerlendirilmesi. H. Ekşi (Ed.), Psikoterapi ve psikolojik danışmada maneviyat kuramlar ve uygulamlar içinde (s. 253-282). İstanbul: Kaknüs Yayınları

Knaus, W.J. (1998). Do it now! Break the procrastination habit. New York: John WileyveSons, Inc.

Middleton, M., \& Midgley, C. (1997). Avoiding the demonstration of lack of ability: An under explored aspect of goal theory. Journal of Educational Psychology, 89, 710-718.

Oginska-Bulink, N. (2013). Negative and positive effects of traumatic experiences in a group of emergency service workers-the role of personal and social resources. Medycyna Pracy, 64(4), $463-472$

Özer, A. ve Altun, E. (2011). Üniversite öğrencilerinin akademik erteleme nedenleri. Mehmet Akif Ersoy Üniversitesi Ĕ̆itim Fakültesi Dergisi, 21, 45 - 72

Polanski, P.J. (2003). Spirituality in supervision. Counselling and Values.47. 131-134

Post, B. C., \& Wade, N. G. (2009). Religion and spirituality in psychotherapy: A practice-friendly review of research. Journal of Clinical Psychology, 65(2), 131-146.

Propst, L. R., Ostrom, R., Watkins, P., Dean, T., \& Mashburn, D. (1992). Comparative efficacy of religious and nonreligious cognitive-behavioral therapy for the treatment of clinical depression in religious individuals. Journal of consulting and clinical psychology, 60(1), 94.

Purdon, C., \& Clark, D. A. (2013). Takıntılarla başa çıkma. Istanbul, Turkey: Psikonet Yayınları

Richards, P. S., Owen, L., \& Stein, S. (1993). A religiously oriented group counseling intervention for self $\square$ defeating perfectionism: A pilot study. Counseling and Values, 37(2), 96-104.

Robbins, C. (2014). Wesleyan narrative pastoral conversations: Coauthoring the parishioner's story through Wesleyan theology, narrative therapy, and pastoral counseling. Asbury Theological Seminary, Kentucky: USA

Rosmarin, D. H., Auerbach, R. P., Bigda-Peyton, J. S., Björgvinsson, T., \& Levendusky, P. E. (2011). Integrating spirituality into cognitive behavioral therapy in an acute psychiatric setting: A pilot study. Journal of Cognitive Psychotherapy: An International Quarterly, 25(4), 287-303.

Rozental, A., Forsström, D., Nilsson, S., Rizzo, A., \& Carlbring, P. (2014). Group versus Internet based cognitive behavioral therapy for procrastination: Study protocol for a randomized controlled trial. Internet Interventions, 1(2), 84-89.

Senecal, C., Julien, E., \& Guay, F. (2003). Role conflict and academic procrastination: A self 
determination perspective. European Journal of Social Psychology, 33(1), 135-145

Scott Richards, P., Berrett, M. E., Hardman, R. K., \& Eggett, D. L. (2006). Comparative efficacy of spirituality, cognitive, and emotional support groups for treating eating disorder inpatients. Eating Disorders, 14(5), 401-415.

Snodgrass, J. (2009). Toward holistic care: Integrating spirituality and cognitive behavioral therapy for older adults. Journal of Religion, Spirituality \& Aging, 21, 219-236.

Solomon, L. J., \& Rothblum, E. D. (1984). Academic procrastination: Frequency and cognitive behavioral correlates. Journal of Counseling Psychology, 31(4), 503.

Şirin, A.B. (2011). Mükemmeliyetçilikle İlgili Psikoeğitim Programının İlköğretim 8.Sinıf Öğrencilerinin Mükemmeliyetçilik Düzeyleri ve Akademik Başarılarına Etkisi. (Yayımlanmamış yüksek lisans tezi). Ankara Üniversitesi: Ankara.

Tan, S.-Y. (2007). Use of prayer and scripture in cognitive-behavioral therapy. Journal of Psychology and Christianity, 26(2), 101-111.

Tran, M. H. V. (2000). Perfectionism, Motivational Orientation and Academic Performance. (Master thesis). Lakehead University, Ontario.

Toker, B., \& Avci, R. (2015). Effect of Cognitive-Behavioral-Theory-Based Skill Training on Academic Procrastination Behaviors of University Students. Educational Sciences: Theory and Practice, 15(5), 11571168.

Uyulgan, M. A., \& Akkuzu, N. (2014). Öğretmen adaylarının akademik içsel motivasyonlarına bir bakış. Kuram ve Uygulamada Eğitim Bilimleri, 14(1), 7-32.

Uzun Özer, R.B. (2005). Akademik Erteleme Davranışı: Yaygınlı̆̆ı, Olası Sebepleri,Cinsiyet Farkı ve Akademik Başarısıyla Olan Ilişkisi. (Yayımlanmamış yüksek lisans tez). Orta Doğu Teknik Üniversitesi Sosyal Bilimler Enstitüsü, Ankara.

Uzun Özer, B. ve Topkaya N. (2005). Akademik erteleme davranışı ve sınav kaygısı arasındaki ilişkiler. 8. Ulusal Psikolojik Danışma ve Rehberlik Kongresi, Eylül, 2005 İstanbul.

Vasegh, S. (2009). Psychiatric treatments involving religion: Psychotherapy from an Islamic perspective. P. Huguelet\& H. G. Koening (Eds.), Religion and Spirituality in Psychiatry (pp. 301-316). Cambridge, UK: Cambridge University Press.

Wang, S., Zhou, Y., Yu, S., Ran, L. W., Liu, X. P., \& Chen, Y. F. (2017). Acceptance and commitment therapy and cognitive-behavioral therapy as treatments for academic procrastination: A randomized controlled group session. Research on Social Work Practice, 27(1), 48-58.

Walker, D. F., Reese, J. B., Hughes, J. P., \& Troskie, M. J. (2010). Addressing religious and spiritual issues in trauma-focused cognitive behavior therapy for children and adolescents. Professional Psychology: Research and Practice, 41(2), 174.

Waschle, K., Allgaier, A., Lachner, A., Fink, S., \& Nückles, M. (2014). Procrastination and self efficacy: Tracing vicious and virtuous circles in self-regulated learning. Learning and Instruction, 29, 103-114.

Yıldız, M. Üniversite Öğrencilerinde Bilişsel Davranışçı Grupla Psikolojik Danışmanın Olumsuz Otomatik Düşünceler ve Fonksiyonel Olmayan Tutumlara Etkisi. Artuklu Insan ve Toplum Bilim Dergisi, 3(1), 1-9. 
8ु. SPIRITUAL PSYCHOLOGY AND COUNSELING 